\title{
The Innovative Trend Analysis Applied to Annual and Seasonal Rainfall in the Tafna Watershed (Algeria)
}

\author{
Afaf Bouklikha ${ }^{1}$ (D), Mohammed $\mathrm{Habi}^{2}$, Abdelkader Elouissi ${ }^{3}$, Benali Benzater ${ }^{3}$, Saaed Hamoudi ${ }^{4}$ \\ ${ }^{1}$ Hassiba Benbouali Chlef University, Faculty of Civil Engineering and Architecture, Department \\ of Hydraulics, Vegetal Chemistry - Water - Energy Laboratory, Chlef, Ouled Fares, Algeria. \\ ${ }^{2}$ Abou Bakr Belkaid University, Faculty of Technology, Department of Hydraulics, Conservation \\ Management of Water, Soil and Forests and Sustainable Development of the Mountainous \\ Laboratory, Tlemcen, Algeria. \\ ${ }^{3}$ Mustapha Stambouli University of Mascara, Faculty of Natural and Life Sciences, Biological \\ Systems and Geomatics Research Laboratory, Mascara, Algeria. \\ ${ }^{4}$ Hassiba Benbouali Chlef University, Faculty of Civil Engineering and Architecture, Department \\ of Hydraulics, water and Environment Laboratory, Chlef, Algeria.
}

Received: 26 May 2020 - Accepted: 10 August 2020

\begin{abstract}
This study analyzes the temporal variability of seasonal and annual rainfall in the Tafna watershed (Northwest Algeria), using a homogeneous monthly rainfall database from 17 stations of 46 years of observation (1970-2015). Possible trends in seasonal and annual variations in rainfall were detected using the innovative trend analysis (ITA), which identifies trends in the low, medium and high values of a series. The results obtained indicate that seasonal rainfall showed a decreasing trend in winter and spring, while increasing trend is detected in summer and autumn. Low and high values categories are the most affected by the decrease in winter, while for spring it is the medium and high values, which are affected. In addition, spring showed the greatest decrease in arithmetic average and standard deviation. On the other hand, summer and autumn, present a growing trend affecting the low and high values, while in autumn, these are the medium and high values. Summer recorded the maximum increase in arithmetic average and standard deviation, and may present a flooding risk in future. Annually, a decreasing trend dominate. Most stations are marked by a decrease in their annual arithmetic means and standard deviation.
\end{abstract}

Keywords: rainfall, trend, ITA, Tafna, Algeria.

\section{A Análise Inovadora de Tendências Aplicada a Chuva Anual E Sazonal na Bacia Hidrográfica de Tafna (Argélia)}

\begin{abstract}
Resumo
Este estudo analisa a variabilidade temporal da precipitação sazonal e anual na bacia hidrográfica de Tafna (Noroeste da Argélia), utilizando uma base de dados homogénea de chuva mensal de 17 estações de 46 anos de observação (19702015). Foram detectadas possíveis tendências nas variações sazonais e anuais da precipitação utilizando a análise de tendências inovadora (ITA), que identifica tendências nos valores baixos, médios e altos de uma série. Os resultados obtidos indicam que a pluviosidade sazonal mostrou uma tendência decrescente no Inverno e na Primavera, enquanto que a tendência crescente é detectada no Verão e no Outono. As categorias de valores baixos e altos são as mais afectadas pela diminuição no Inverno, enquanto que para a Primavera são os valores médios e altos, que são afectados. Além disso, a Primavera mostrou a maior diminuição na média aritmética e no desvio padrão. Por outro lado, o Verão e o Outono, apresentam uma tendência crescente que afecta os valores baixos e altos, enquanto que no Outono, estes são os valores médios e altos. O Verão registou o aumento máximo da média aritmética e do desvio-padrão, e pode apresentar um risco de inundação no futuro. Anualmente, predomina uma tendência decrescente. A maioria das estações é marcada por uma diminuição das suas médias aritméticas anuais e do desvio padrão.
\end{abstract}

Palavras-chave: chuva, tendência, ITA, Tafna, Argélia. 


\section{Introduction}

Precipitation, one of the fundamental components of the water cycle, is the main source of water supply. Their needs will increase in the future due to population growth and the socioeconomic development of communities. The variability of precipitation directly involves the two extremes, droughts and floods. These two meteorological hazards can both threaten water supply, irrigation and industry, and alter country strategies by causing catastrophic damage, both human and material (Wang et al., 2020; Benzater et al., 2019; Kreibich et al., 2017; Ghenim et al., 2016; Labban, 2016; Milly et al., 2008).

The biggest challenge for these water resources is climate change. These changes are caused either directly (internal variability) or indirectly (external variability or climate change, due to anthropogenic activities) (Mohorji et al., 2017; IPCC, 2013; 2007).

One assessment finds that the study of precipitation trends has become an increasingly active research topic for effective regional management of water resources and associated risks (Sun et al., 2018; Fatichi et al., 2012; Milly et al., 2008).

Algeria is one of the countries hard hit by these climatic hazards affecting the entire territory (Elouissi, 2016; Elouissi et al., 2016; Taibi et al., 2013).

Highlighting the precipitation evolution and its impacts is a key tool for planning, adaptation, mitigation to these meteorological hazards and decision-making (Yevjevich et al., 1984). The trends detection, spatial and temporal, is an important step for the analysis of this evolution (Sayemuzzaman et al., 2013). To better understand this evolution, several works have been carried out in the Mediterranean and in Algeria, in particular in the catchment area of Tafna (Northwest Algeria). The work of (Ghenim et al., 2011) on precipitation in the Meffrouche and Beni Bahdel dams during the period 1946-2009, detected moderate sequences of drought and humidity, but with a slight dry tendency, although some years have been very wet or extremely dry. Taibi et al. (2013) studied precipitation in northern Algeria over a period of seven decades (1936-2009) and found that the decade 1980-1990 was the most deficient. Again, Elouissi et al., 2016 found a decrease in rainfall in the Macta, the underlying catchment area of the Tafna, during the period 1970-2011. The most brutal and significant fluctuation in the far west of Algeria is observed around the 1980s during which there was a fairly significant decrease in annual precipitation. This period of deficit has been characterized since then by its intensity and duration (Meddi et al., 2009). The interannual variability of annual precipitation is marked by a significant decrease of more than $20 \%$ in the Tafna catchment area. This decline was observed in the second half of the 1970s (Meddi et al., 2010). The average precipitation deficit, detected after 1970 , is $26 \%$; it is mainly observed during the winter and spring season (Ghenim et al., 2014;
2010). Since 1970, this decrease in precipitation has had a significant impact on the reduction of approximately $62 \%$ of runoff (Meddi et al., 2013).

In recent decades, several methods have been developed to analyze trends in precipitation time series such as the Bravais-Pearson coefficient $(r)$, the Tau $(\tau)$ of the Mann-Kendall test and the Rho ( $\rho)$ of the Spearman test. Recently, an innovative method of trend analysis (ITA), proposed by Sen (2012), was applied to identify trends in precipitation, water quality, solar radiation and evaporation in different regions of the world (Ahmad et al., 2018; Caloiero et al., 2018; Zhou et al., 2018; Dabanli et al., 2016; Kisi, 2015). This method allows the graphical evaluation of trends in low, medium and high values in the time series.

The aim of this article is to identify the spatio-temporal trends of seasonal and annual rainfall in the Tafna watershed (Northwest Algeria), by applying the Innovative Trend Analysis (ITA) on 17 stations during a period of 46 years $(1970-2015)$.

\section{Study Area and Data}

The Tafna watershed, located at the extreme west of Algeria. It is bounded by $1^{\circ}$ and $2^{\circ}$ west longitude and $34^{\circ} 5^{\prime}$ at $35^{\circ} 3^{\prime}$ north latitude. Covers an area of $7245 \mathrm{~km}^{2}$, less than one third of its surface area is located on Moroccan territory. However, $5340 \mathrm{~km}^{2}$ is on the Algerian territory (Aboura, 2006; $\mathrm{ABH}, 2006$ ). The basin is delimited by Tlemcen Mountains, mainly composed of mountains in the south (800 to $1400 \mathrm{~m}$ of altitude). This orographic structure, which is dominated to the north by the Taras Mountains $(1081 \mathrm{~m})$ of narrow width, constitutes an important barrier against precipitation (Meddi et al., 2013). The hydrographic network of the Tafna River is composed of two main wadis, the East Isser and the Tafna. It takes its source in the mountains of Tlemcen.

The soils of the Tafna basin consist of four major groups:

- The alluvial soil covering the low terraces and floodplains of the wadis;

- The stony land in the foothills of the mounts of Tlemcen and of Traras;

- The red soils crust, localized in the plains of Maghnia and Ouled Riah;

- Marly lands, covering much of the region of Tlemcen (Bouanani, 2005).

Vegetation is a key factor in rapid surface runoff, evaporation rate and retention basin. The presence of vegetation will therefore act as a regulator in the flow regime (Bouchelkia et al., 2013).

The climate of the Tafna Basin is comparable to that of the entire Mediterranean region of North Africa (Meddi et al., 2013). The general rainfall pattern is comparable to that of the semi-arid Mediterranean regions of northern 
Algeria (Meddi et al., 2010), with two principal seasons: a long dry warm summer-autumn and a winter-spring with frequent heavy precipitations. The average annual temperature varies from $11^{\circ} \mathrm{C}$ in winter to $28{ }^{\circ} \mathrm{C}$ in summer (Zettam et al., 2017; Taleb et al., 2008). This system is marked by winter rainfall with peaks in December, January and February, and a long period of dryness from June to September. Annual rainfall varies between 240 and $688 \mathrm{~mm}$. year-1. This system is also marked by high spatial and temporal variability in total rainfall (Meddi et al., 2010).

Monthly rainfall data are collected from ANRH (National Agency for Water Resources). Stations with more $10 \%$ of gaps were removed. Therefore, 17 stations are selected (Fig. 1). Outlier detection and filling gaps are made using Hydrolab software (Hydrolab, 2010) was developed by J.P. Laborde, professor at the University of Sofia Antipolis, in October 1998. Integrated in Excel, it allows a simple use of hydrological tools. These steps are essential and allowed to build a database with continuous records period from September 1970 to December 2015 (Meddi et al., 2010; Elmeddahi, 2016; Elouissi et al., 2017). The first step is to form groups of neighboring stations for each month by considering matrices, which are classified into columns of monthly values. Each pair of these matrices is subject to outlier detection. The accumulated residuals method is applied. Missing data were estimated using Hydrolab Excel Macro (Hydrolab, 2010). These macros use PCA (Principal Component Analysis) to estimate missing data. Seven to eight iterations are necessary to stabilize the process According to Laborde (2013). This criterion allowed the selection of 17 stations with a continuous recording period from 1970 to 2015 .

\section{Methodology}

The ITA methodology has been proposed by Sen (2012), this method does not require restrictive assumptions such as those commonly used in the Mann Kendall trend test and Spearman's rho test. In addition, low, medium and high values of a parameter can be evaluated graphically by this method (Kisi et al., 2014). The concept is based on the fact that if two time series are identical, so their scatter points will fall almost along the line 1:1 $\left(45^{\circ}\right)$. The hydrometeorological time series is first divided into two equal parts and arranged separately in ascending order. The first half is placed on X-axis, while the second on Y-axis to obtain a scatter plot. The 1:1 $\left(45^{\circ}\right)$ straight line divides the diagram into two equal triangular sections, where the higher (lower) triangular area is for the increa-

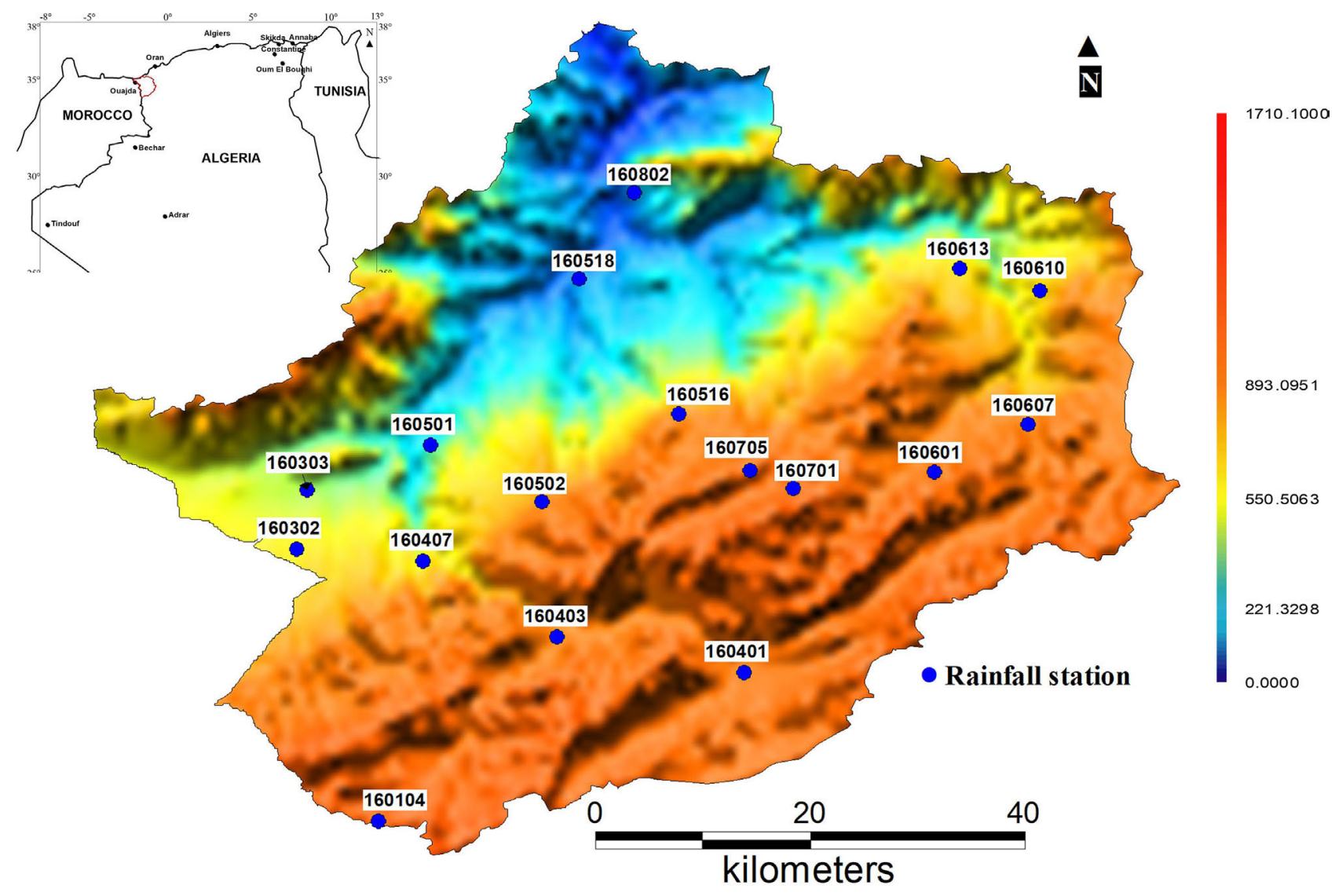

Figure 1 - Tafna watershed and stations locations. 
sing (decreasing) trend element. If the scattering points appear on or near the $1: 1\left(45^{\circ}\right)$ straight line, this means that there is no significant trend in the hydrometeorological recordings. Else, if the points are above (below) the $1: 1$ straight line $\left(45^{\circ}\right)$, it is possible to confirm an increasing (decreasing) trend in the time series (Dabanli et al., 2016; Sen 2012, 2014). The plot can show possible partial trends for "low", "medium" and "high" precipitation data (Öztopal and Sen, 2016) (Fig. 2).

As the dispersion of the points is non-parametric, the serial correlation coefficient does not become effective in this trend study.

As supplementary information, the arithmetic means $\left(m_{1}\right.$ and $\left.m_{2}\right)$, standard deviations $\left(s_{1}\right.$ and $\left.s_{2}\right)$ of the halfseries (1970-1992 and 1993-2015) and the trend slope (S) are represented in ITA template (Fig. 2). The latter is calculated using Eq. (1) (Elouissi et al., 2016; Sen, 2014):

$$
S=\frac{\left(m_{2}-m_{1}\right)}{\left(\frac{n}{2}\right)}
$$

where $n$ is data number.

In addition, tables offer linguistic interpretation where a trend is assigned to each section (low, medium and high). Three symbols are used $(+,-, 0)$ indicating respectively increasing, decreasing and no trend existence.
(Elouissi et al., 2016). In addition, the comparison between the arithmetic means (standard deviation) of the two halves is presented on the tables as a percentage of variation.

\section{Results and Discussion}

To detect trends in seasonal and annual precipitation, the ITA method was applied to the 17 rainfall stations in the Tafna watershed during the period (1970-2015). The trend calculations are achieved through an R Package and the results are shown in Figs. 3 to 7.

By examining Figs. 3 to 7 , Tables 1 to 5 are created. These summarize ITA parameters $\left(m_{1}, s_{1}, m_{2}, s_{2}\right.$ and $\left.S\right)$. In addition, it presents the precipitation trends for each station (last column) and for each rainfall category (low, medium and high).

The trend frequencies for each rain category are presented in Table 6.

\subsection{Seasonal Trends}

The rainfall trends in each season detected by the ITA are summarized in Tables 1 to 4 . Winter rainfall (Table 1) is dominated by negative trends. Only two stations 160104 (South of basin) and 160518 (North of basin) exhibits significant increasing trend (12\%). The low and

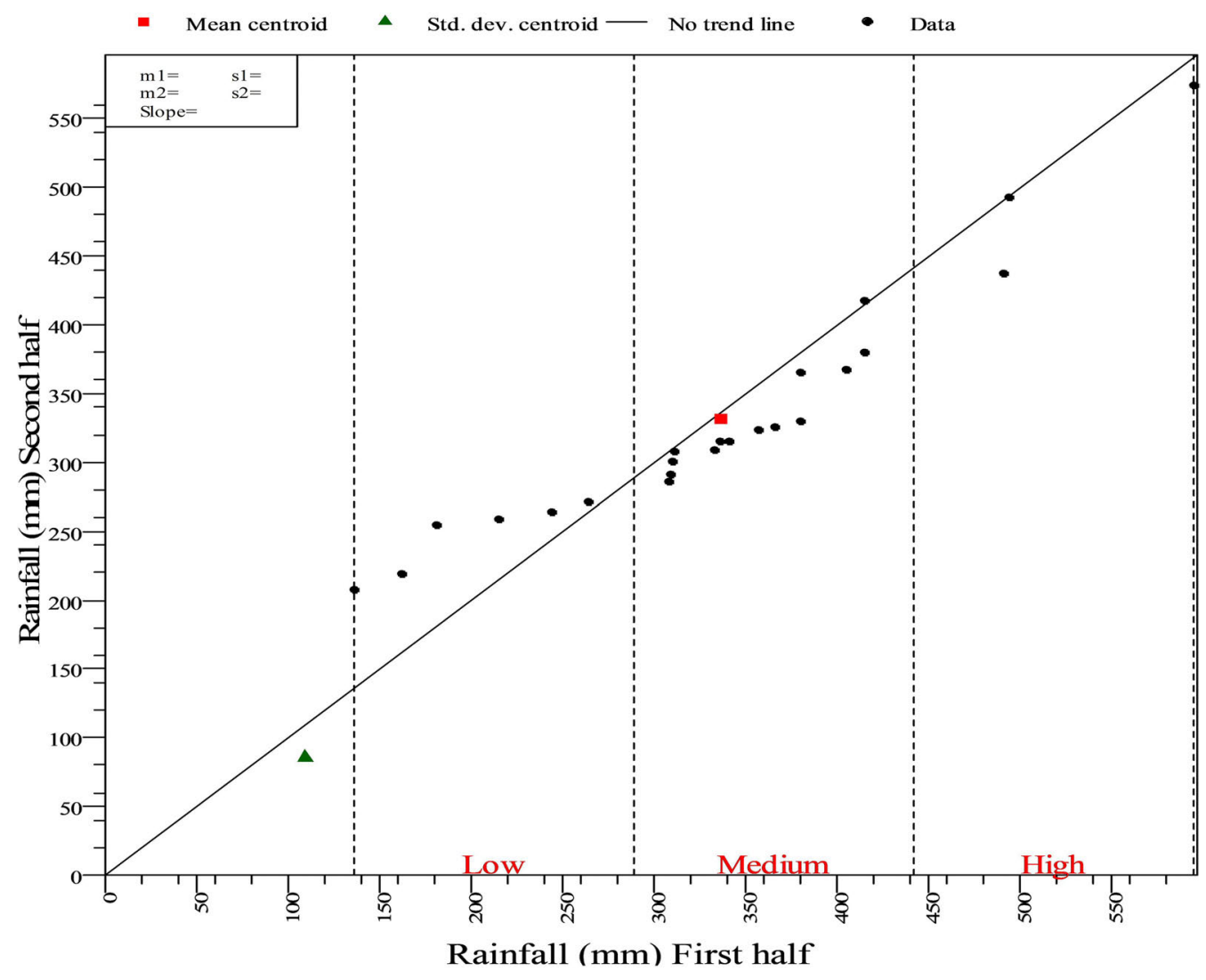

Figure 2 - Innovative trend template. 


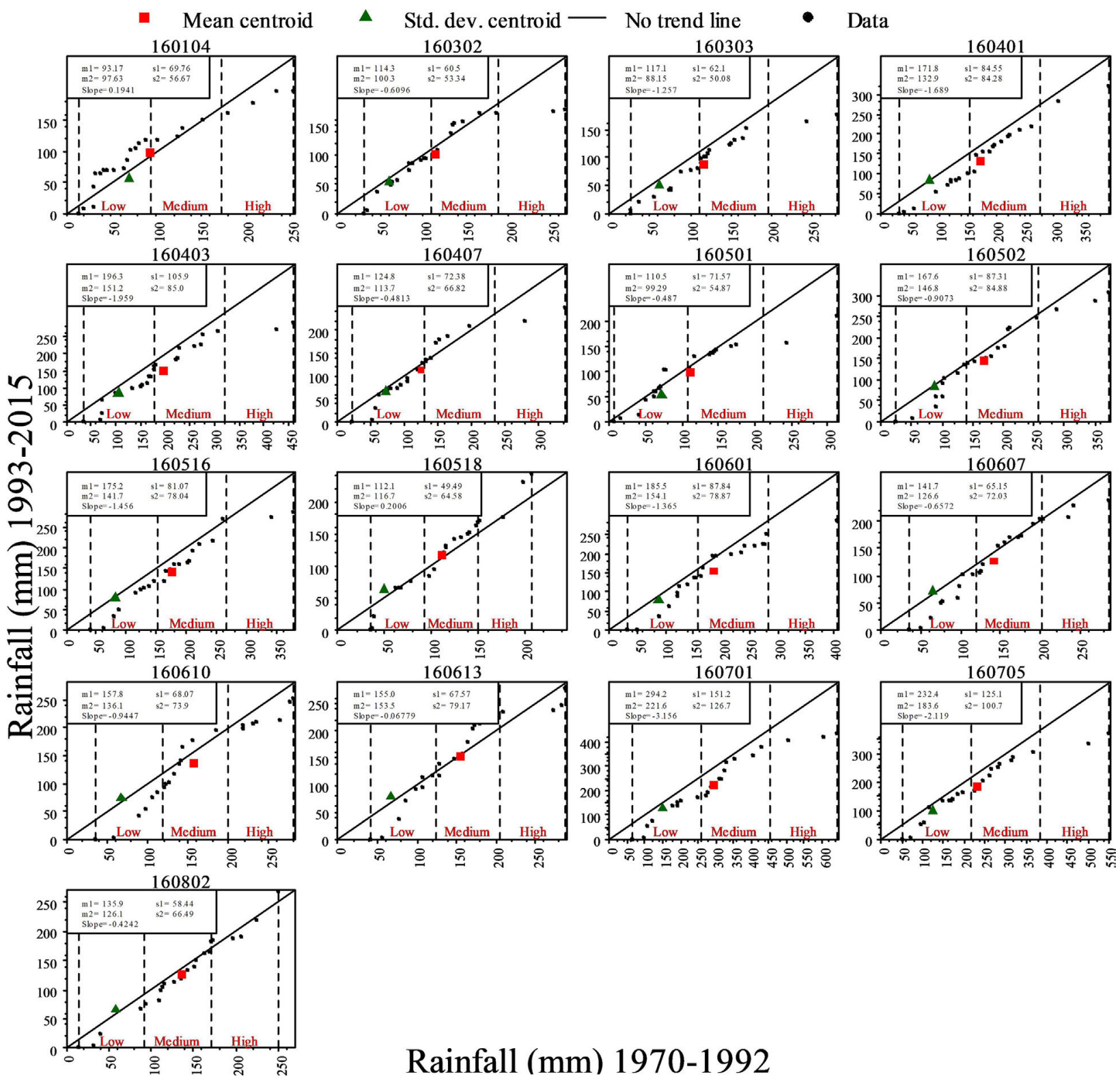

Figure 3 - Winter rainfall trend. 


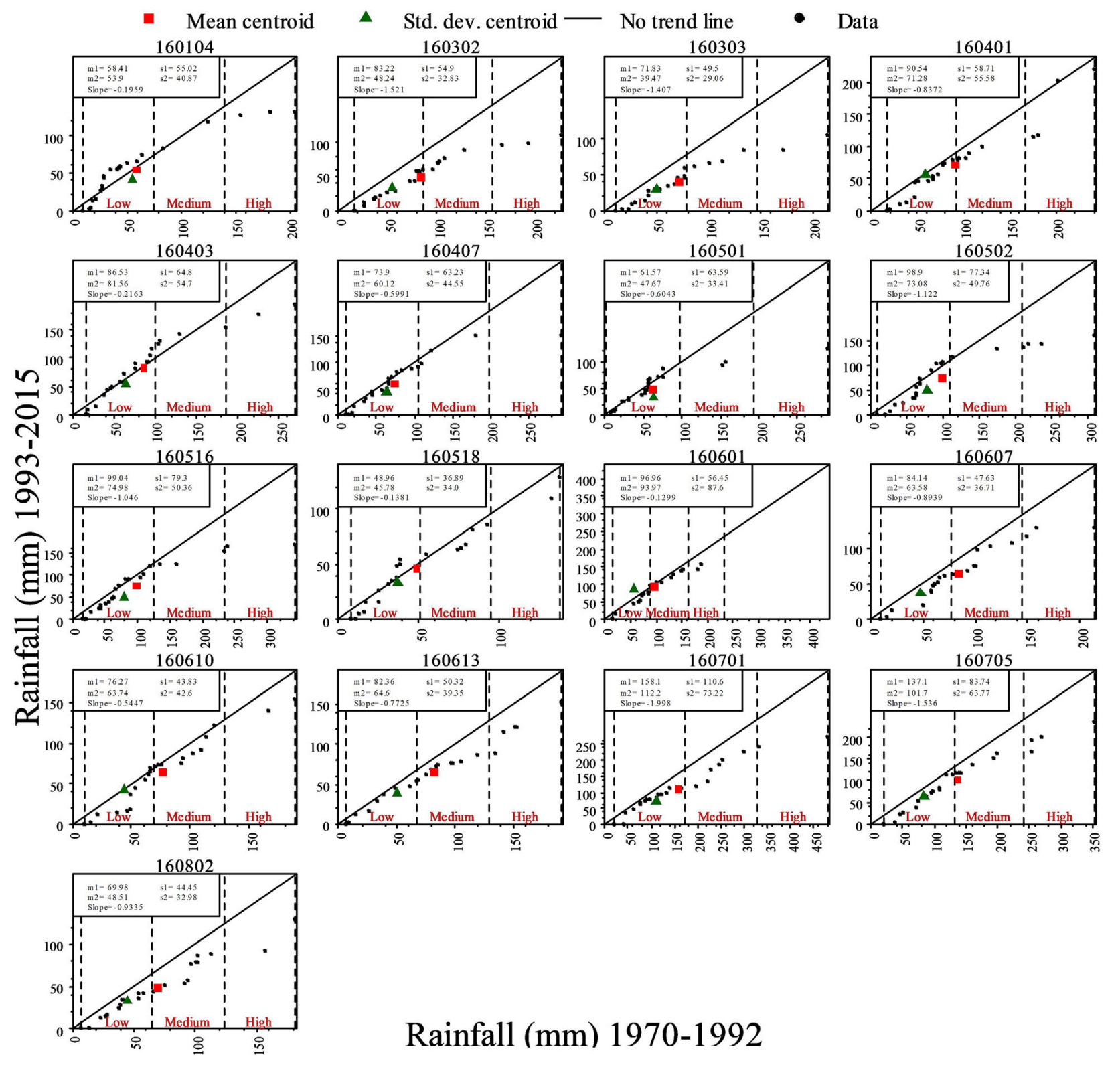

Figure 4 - Spring rainfall trend. 


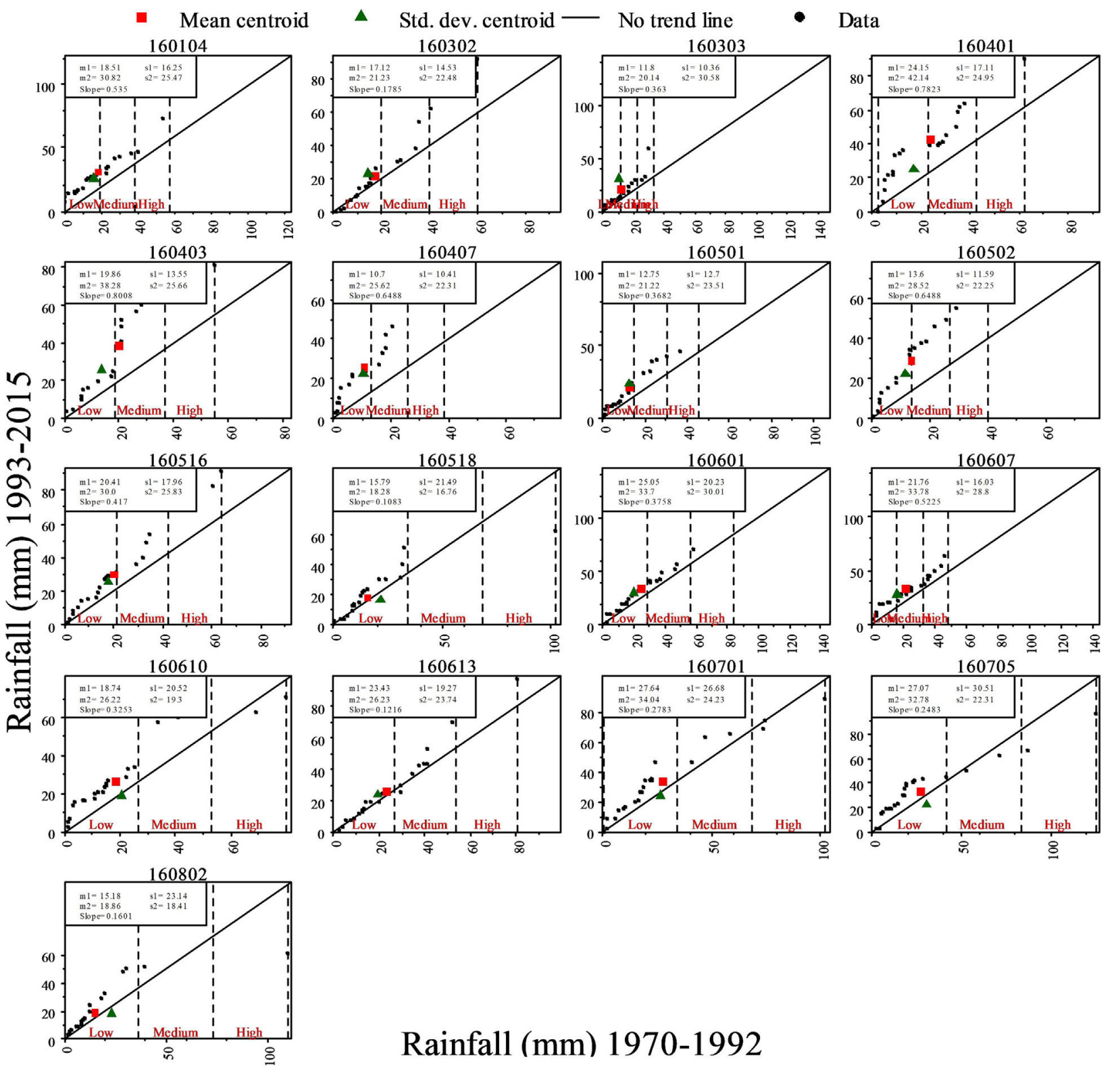

Figure 5 - Summer rainfall trend. 


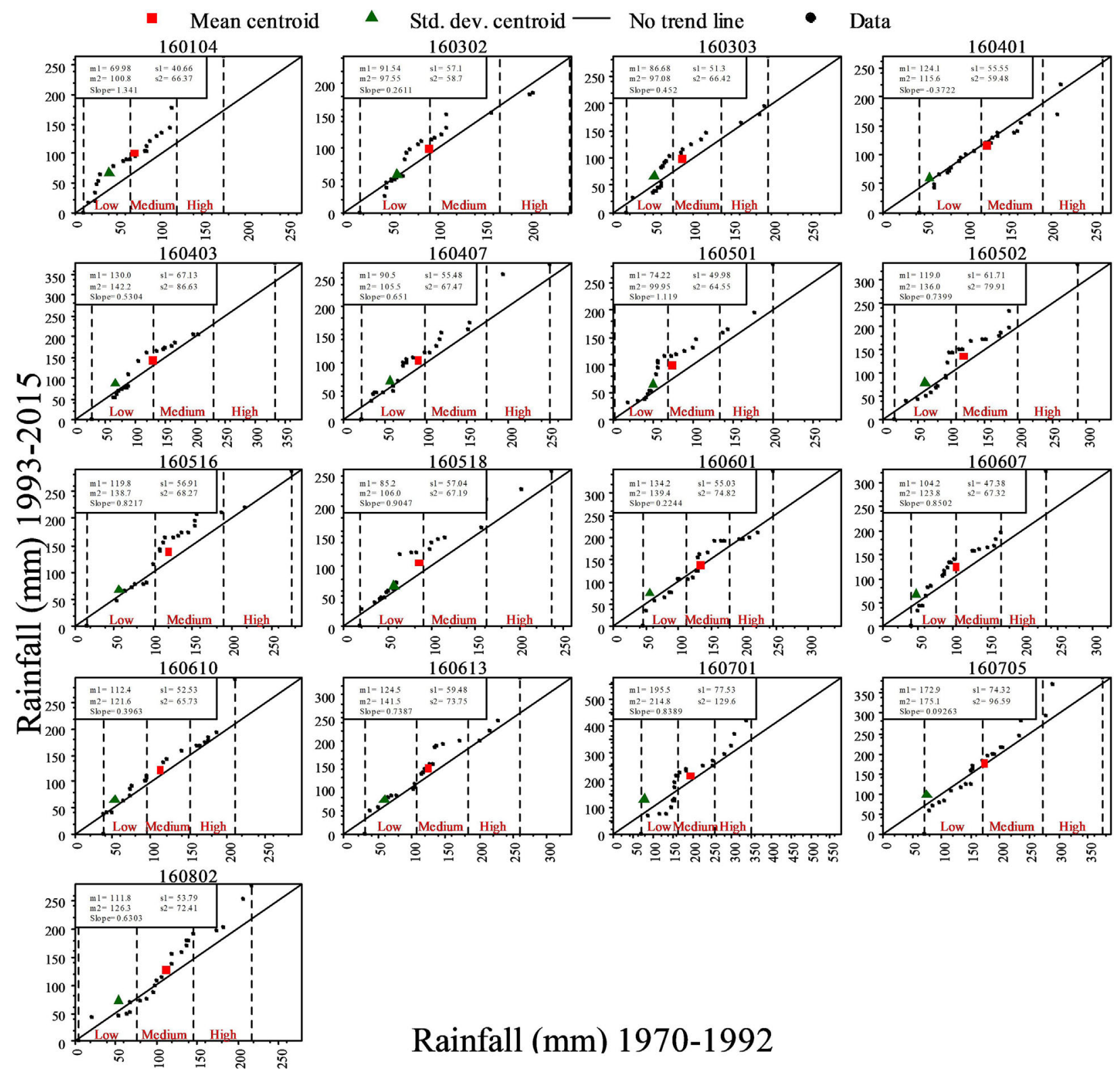

Figure 6 - Autumn rainfall trend. 

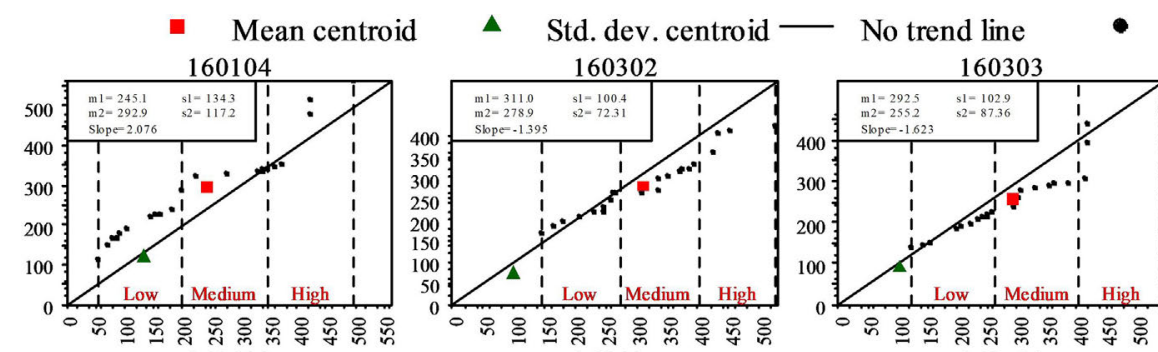

Data
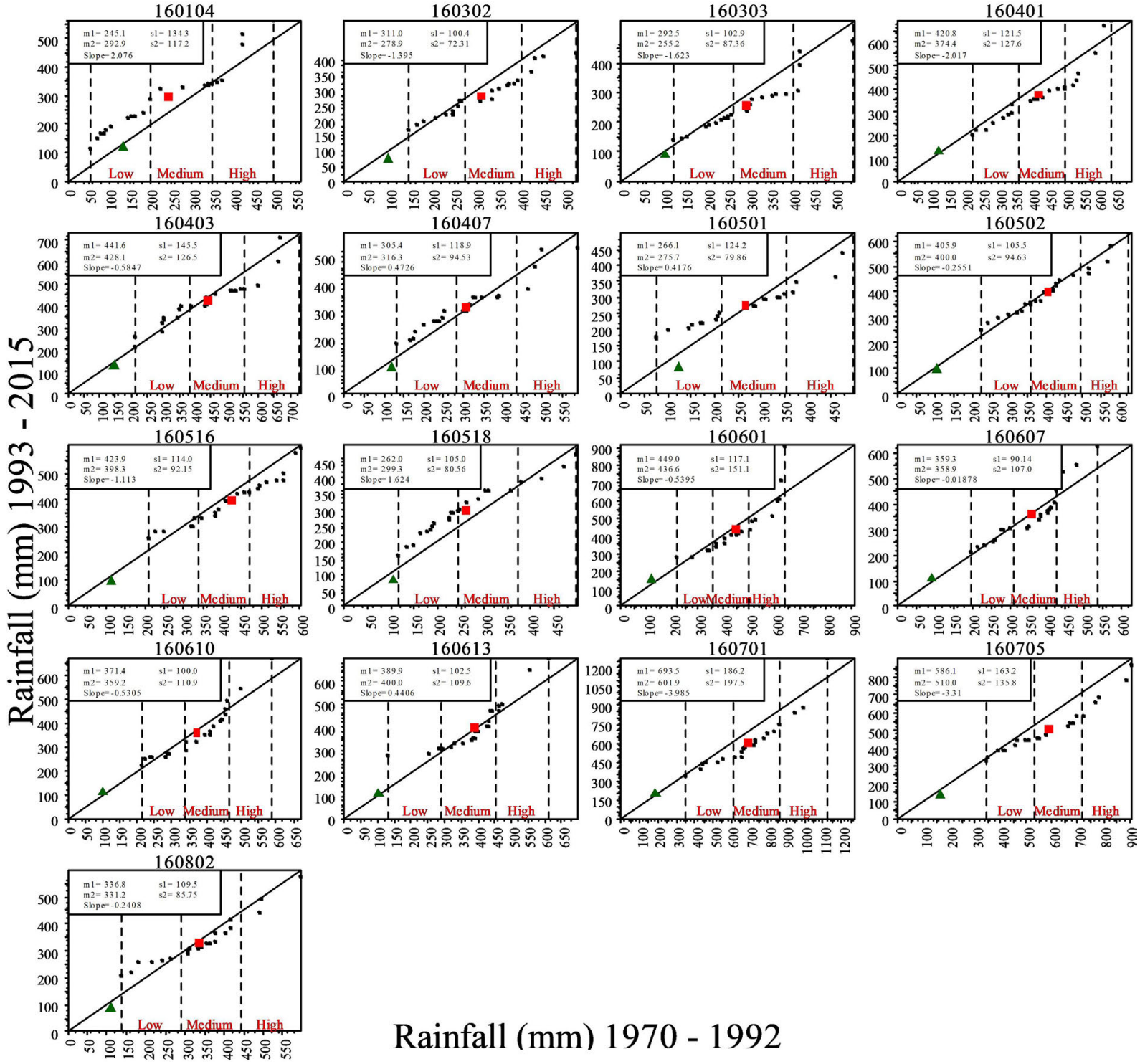

\section{Rainfall (mm) 1970 - 1992}

Figure 7 - Annual rainfall trend. 
Table 1 - Innovative trend analysis parameters (winter rainfall).

\begin{tabular}{|c|c|c|c|c|c|c|c|c|c|c|c|}
\hline \multirow{2}{*}{$\begin{array}{l}\text { Station } \\
\mathrm{N}^{\circ}\end{array}$} & \multicolumn{2}{|c|}{ 1970-1992 } & \multicolumn{2}{|c|}{ 1993-2015 } & \multirow{2}{*}{$\begin{array}{c}\text { Trend } \\
\text { Slope (-) }\end{array}$} & \multicolumn{2}{|c|}{ Variation } & \multicolumn{4}{|c|}{ Interpretation } \\
\hline & Mean (mm) & Std. D. (mm) & Mean (mm) & Std. D. (mm) & & Mean (\%) & Std. D. (\%) & Low & Medium & High & Station trend \\
\hline 160104 & 93.2 & 69.8 & 97.6 & 56.7 & 0.194 & 4.72 & -18.77 & + & + & - & + \\
\hline 160302 & 114.3 & 60.5 & 100.3 & 53.3 & -0.610 & -12.25 & -11.90 & - & + & - & - \\
\hline 160303 & 117.1 & 62.1 & 88.1 & 50.1 & -1.257 & -24.77 & -19.32 & - & - & - & - \\
\hline 160401 & 171.8 & 84.5 & 132.9 & 84.3 & -1.689 & -22.64 & -0.24 & - & - & - & - \\
\hline 160403 & 196.3 & 105.9 & 151.2 & 85.0 & -1.959 & -22.98 & -19.74 & - & - & - & - \\
\hline 160407 & 124.8 & 72.4 & 113.7 & 66.8 & -0.481 & -8.89 & -7.73 & - & + & - & - \\
\hline 160501 & 110.5 & 71.6 & 99.3 & 54.9 & -0.487 & -10.14 & -23.32 & - & - & - & - \\
\hline 160502 & 167.6 & 87.3 & 146.8 & 84.9 & -0.907 & -12.41 & -2.75 & - & - & - & - \\
\hline 160516 & 175.2 & 81.1 & 141.7 & 78.0 & -1.456 & -19.12 & -3.82 & - & - & - & - \\
\hline 160518 & 112.1 & 49.5 & 116.7 & 64.6 & 0.201 & 4.10 & 30.51 & - & + & + & + \\
\hline 160601 & 185.5 & 87.8 & 154.1 & 78.9 & -1.365 & -16.93 & -10.14 & - & - & - & - \\
\hline 160607 & 141.7 & 65.2 & 126.6 & 72.0 & -0.657 & -10.66 & 10.43 & - & 0 & - & - \\
\hline 160610 & 157.8 & 68.1 & 136.1 & 73.9 & -0.945 & -13.75 & 8.52 & - & + & - & - \\
\hline 160613 & 155.0 & 67.6 & 153.5 & 79.2 & -0.068 & -0.97 & 17.16 & - & + & - & - \\
\hline 160701 & 294.2 & 151.2 & 221.6 & 126.7 & -3.156 & -24.68 & -16.20 & - & - & - & - \\
\hline 160705 & 232.4 & 125.1 & 183.6 & 100.7 & -2.119 & -21.00 & -19.50 & - & - & - & - \\
\hline 160802 & 135.9 & 58.4 & 126.1 & 66.5 & -0.424 & -7.21 & 13.87 & - & - & - & - \\
\hline
\end{tabular}

Table 2 - Innovative trend analysis parameters (spring rainfall).

\begin{tabular}{|c|c|c|c|c|c|c|c|c|c|c|c|}
\hline \multirow{2}{*}{$\begin{array}{l}\text { Station } \\
\mathrm{N}^{\circ}\end{array}$} & \multicolumn{2}{|c|}{ 1970-1992 } & \multicolumn{2}{|c|}{ 1993-2015 } & \multirow{2}{*}{$\begin{array}{c}\text { Trend } \\
\text { Slope (-) }\end{array}$} & \multicolumn{2}{|c|}{ Variation } & \multicolumn{4}{|c|}{ Interpretation } \\
\hline & Mean (mm) & Std. D. (mm) & Mean (mm) & Std. D. (mm) & & Mean (\%) & Std. D. (\%) & Low & Medium & High & Station trend \\
\hline 160104 & 58.4 & 55.0 & 53.9 & 40.9 & -0.196 & -7.71 & -25.64 & + & - & - & - \\
\hline 160302 & 83.2 & 54.9 & 48.2 & 32.8 & -1.521 & -42.07 & -40.26 & - & - & - & - \\
\hline 160303 & 71.8 & 49.5 & 39.5 & 29.1 & -1.407 & -44.99 & -41.21 & - & - & - & - \\
\hline 160401 & 90.5 & 58.7 & 71.3 & 55.6 & -0.837 & -21.22 & -5.28 & - & - & - & - \\
\hline 160403 & 86.5 & 64.8 & 81.6 & 54.7 & -0.216 & -5.66 & -15.59 & + & + & - & - \\
\hline 160407 & 73.9 & 63.2 & 60.1 & 44.6 & -0.599 & -18.67 & -29.43 & - & - & - & - \\
\hline 160501 & 61.6 & 63.6 & 47.7 & 33.4 & -0.604 & -22.56 & -47.48 & 0 & - & - & - \\
\hline 160502 & 98.9 & 77.3 & 73.1 & 49.8 & -1.122 & -26.09 & -35.58 & - & - & - & - \\
\hline 160516 & 99.0 & 79.3 & 75.0 & 50.4 & -1.046 & -24.24 & -36.44 & - & - & - & - \\
\hline 160518 & 49.0 & 36.9 & 45.8 & 34.0 & -0.138 & -6.53 & -7.86 & - & - & - & - \\
\hline 160601 & 97.0 & 56.5 & 94.0 & 87.6 & -0.130 & -3.09 & 55.04 & - & - & - & - \\
\hline 160607 & 84.1 & 47.6 & 63.6 & 36.7 & -0.894 & -24.38 & -22.90 & - & - & - & - \\
\hline 160610 & 76.3 & 43.8 & 63.7 & 42.6 & -0.545 & -16.51 & -2.74 & - & - & - & - \\
\hline 160613 & 82.4 & 50.3 & 64.6 & 39.4 & -0.773 & -21.60 & -21.67 & - & - & - & - \\
\hline 160701 & 158.1 & 110.6 & 112.2 & 73.2 & -1.998 & -29.03 & -33.82 & - & - & - & - \\
\hline 160705 & 137.1 & 83.7 & 101.7 & 63.8 & -1.536 & -25.82 & -23.78 & - & - & - & - \\
\hline 160802 & 70.0 & 44.5 & 48.5 & 33.0 & -0.934 & -30.71 & -25.84 & - & - & - & - \\
\hline
\end{tabular}


Table 3 - Innovative trend analysis parameters (summer rainfall).

\begin{tabular}{|c|c|c|c|c|c|c|c|c|c|c|c|}
\hline \multirow{2}{*}{$\begin{array}{l}\text { Station } \\
\mathrm{N}^{\circ}\end{array}$} & \multicolumn{2}{|c|}{ 1970-1992 } & \multicolumn{2}{|c|}{$1993-2015$} & \multirow{2}{*}{$\begin{array}{c}\text { Trend } \\
\text { Slope (-) }\end{array}$} & \multicolumn{2}{|c|}{ Variation } & \multicolumn{4}{|c|}{ Interpretation } \\
\hline & Mean (mm) & Std. D. (mm) & Mean (mm) & Std. D. (mm) & & Mean (\%) & Std. D. (\%) & Low & Medium & High & Station trend \\
\hline 160104 & 18.5 & 16.3 & 30.8 & 25.5 & 0.535 & 66.49 & 56.44 & + & + & + & + \\
\hline 160302 & 17.1 & 14.5 & 21.2 & 22.5 & 0.179 & 23.98 & 55.17 & + & + & + & + \\
\hline 160303 & 11.8 & 10.4 & 20.1 & 30.6 & 0.363 & 70.34 & 194.23 & + & + & + & + \\
\hline 160401 & 24.2 & 17.1 & 42.1 & 25.0 & 0.782 & 73.97 & 46.20 & + & + & + & + \\
\hline 160403 & 19.9 & 13.6 & 38.3 & 25.7 & 0.801 & 92.46 & 88.97 & + & + & + & + \\
\hline 160407 & 10.7 & 10.4 & 25.6 & 22.3 & 0.649 & 139.25 & 114.42 & + & + & + & + \\
\hline 160501 & 12.7 & 12.7 & 21.2 & 23.5 & 0.368 & 66.93 & 85.04 & + & + & + & + \\
\hline 160502 & 13.6 & 11.6 & 28.5 & 22.3 & 0.649 & 109.56 & 92.24 & + & + & + & + \\
\hline 160516 & 20.4 & 18.0 & 30.0 & 25.8 & 0.417 & 47.06 & 43.33 & + & + & + & + \\
\hline 160518 & 15.8 & 21.5 & 18.3 & 16.8 & 0.108 & 15.82 & -21.86 & + & 0 & - & + \\
\hline 160601 & 25.1 & 20.2 & 33.7 & 30.0 & 0.376 & 34.26 & 48.51 & + & + & + & + \\
\hline 160607 & 21.8 & 16.0 & 33.8 & 28.8 & 0.523 & 55.05 & 80.00 & + & + & + & + \\
\hline 160610 & 18.7 & 20.5 & 26.2 & 19.3 & 0.325 & 40.11 & -5.85 & + & + & - & + \\
\hline 160613 & 23.4 & 19.3 & 26.2 & 23.7 & 0.122 & 11.97 & 22.80 & + & + & + & + \\
\hline 160701 & 27.6 & 26.7 & 34.0 & 24.2 & 0.278 & 23.19 & -9.36 & + & + & - & + \\
\hline 160705 & 27.1 & 30.5 & 32.8 & 22.3 & 0.248 & 21.03 & -26.89 & + & - & - & + \\
\hline 160802 & 15.2 & 23.1 & 18.9 & 18.4 & 0.160 & 24.34 & -20.35 & + & + & - & + \\
\hline
\end{tabular}

Table 4 - Innovative trend analysis parameters (autumn rainfall).

\begin{tabular}{|c|c|c|c|c|c|c|c|c|c|c|c|}
\hline \multirow{2}{*}{$\begin{array}{l}\text { Station } \\
\mathrm{N}^{\circ}\end{array}$} & \multicolumn{2}{|c|}{ 1970-1992 } & \multicolumn{2}{|c|}{$1993-2015$} & \multirow{2}{*}{$\begin{array}{c}\text { Trend } \\
\text { Slope (-) }\end{array}$} & \multicolumn{2}{|c|}{ Variation } & \multicolumn{4}{|c|}{ Interpretation } \\
\hline & Mean (mm) & Std. D. (mm) & Mean (mm) & Std. D. (mm) & & Mean (\%) & Std. D. (\%) & Low & Medium & High & Station trend \\
\hline 160104 & 70.0 & 40.7 & 100.8 & 66.4 & 1.341 & 44.00 & 63.14 & + & + & + & + \\
\hline 160302 & 91.5 & 57.1 & 97.5 & 58.7 & 0.261 & 6.56 & 2.80 & + & + & - & + \\
\hline 160303 & 86.7 & 51.3 & 97.1 & 66.4 & 0.452 & 12.00 & 29.43 & + & + & 0 & + \\
\hline 160401 & 124.1 & 55.6 & 115.6 & 59.5 & -0.370 & -6.85 & 7.01 & - & - & + & - \\
\hline 160403 & 130.0 & 67.1 & 142.2 & 86.6 & 0.53 & 9.38 & 29.06 & 0 & + & + & + \\
\hline 160407 & 90.5 & 55.5 & 105.5 & 67.5 & 0.651 & 16.57 & 21.62 & + & + & + & + \\
\hline 160501 & 74.2 & 50.0 & 100.0 & 64.5 & 1.119 & 34.77 & 29.00 & + & + & + & + \\
\hline 160502 & 119.0 & 61.7 & 136.0 & 79.9 & 0.740 & 14.29 & 29.50 & - & + & + & + \\
\hline 160516 & 119.8 & 56.9 & 138.7 & 68.3 & 0.822 & 15.78 & 20.04 & - & + & + & + \\
\hline 160518 & 85.2 & 57.0 & 106.0 & 67.2 & 0.905 & 24.41 & 17.89 & + & + & + & + \\
\hline 160601 & 134.2 & 55.0 & 139.4 & 74.8 & 0.224 & 3.87 & 36.00 & - & + & - & + \\
\hline 160607 & 104.2 & 47.4 & 123.8 & 67.3 & 0.850 & 18.81 & 41.98 & + & + & + & + \\
\hline 160610 & 112.4 & 52.5 & 121.6 & 65.7 & 0.396 & 8.19 & 25.14 & + & + & + & + \\
\hline 160613 & 124.5 & 59.5 & 141.5 & 73.7 & 0.739 & 13.65 & 23.87 & + & + & + & + \\
\hline 160701 & 195.5 & 77.5 & 214.8 & 129.6 & 0.839 & 9.87 & 67.23 & - & + & + & + \\
\hline 160705 & 172.9 & 74.3 & 175.1 & 96.6 & 0.093 & 1.27 & 30.01 & - & + & + & + \\
\hline 160802 & 111.8 & 53.8 & 126.3 & 72.4 & 0.630 & 12.97 & 34.57 & - & + & + & + \\
\hline
\end{tabular}


Table 5 - Innovative trend analysis parameters (annual rainfall).

\begin{tabular}{|c|c|c|c|c|c|c|c|c|c|c|c|}
\hline \multirow{2}{*}{$\begin{array}{l}\text { Station } \\
\mathrm{N}^{\circ}\end{array}$} & \multicolumn{2}{|c|}{ 1970-1992 } & \multicolumn{2}{|c|}{ 1993-2015 } & \multirow{2}{*}{$\begin{array}{c}\text { Trend } \\
\text { Slope (-) }\end{array}$} & \multicolumn{2}{|c|}{ Variation } & \multicolumn{4}{|c|}{ Interpretation } \\
\hline & Mean (mm) & Std. D. (mm) & Mean (mm) & Std. D. (mm) & & Mean $(\%)$ & Std. D. (\%) & Low & Medium & High & Station trend \\
\hline 160104 & 245.1 & 134.3 & 292.9 & 117.2 & 2.076 & 19.50 & -12.73 & + & + & + & + \\
\hline 160302 & 311.0 & 100.4 & 278.9 & 72.3 & -1.395 & -10.32 & -27.99 & 0 & - & - & - \\
\hline 160303 & 292.5 & 102.9 & 255.2 & 87.4 & -1.623 & -12.75 & -15.06 & - & - & - & - \\
\hline 160401 & 420.8 & 121.5 & 374.4 & 127.6 & -2.017 & -11.03 & 5.02 & - & - & - & - \\
\hline 160403 & 441.6 & 145.5 & 428.1 & 126.5 & -0.585 & -3.06 & -13.06 & + & - & - & - \\
\hline 160407 & 305.4 & 118.9 & 316.3 & 94.5 & 0.473 & 3.57 & -20.52 & + & 0 & - & + \\
\hline 160501 & 266.1 & 124.2 & 275.7 & 79.9 & 0.418 & 3.61 & -35.67 & + & - & - & + \\
\hline 160502 & 405.9 & 105.5 & 400.0 & 94.6 & -0.255 & -1.45 & -10.33 & + & 0 & - & - \\
\hline 160516 & 423.9 & 114.0 & 398.3 & 92.2 & -1.113 & -6.04 & -19.12 & + & - & - & - \\
\hline 160518 & 262.0 & 105.0 & 299.3 & 80.6 & 1.624 & 14.24 & -23.24 & + & + & - & + \\
\hline 160601 & 449.0 & 117.1 & 436.6 & 151.1 & -0.540 & -2.76 & 29.04 & + & + & - & - \\
\hline 160607 & 359.3 & 90.1 & 358.9 & 107.0 & -0.019 & -0.11 & 18.76 & 0 & - & + & - \\
\hline 160610 & 371.4 & 100.0 & 359.2 & 110.9 & -0.531 & -3.28 & 10.90 & - & - & + & - \\
\hline 160613 & 389.9 & 102.5 & 400.0 & 109.6 & 0.441 & 2.59 & 6.93 & + & - & + & + \\
\hline 160701 & 693.5 & 186.2 & 601.9 & 197.5 & -3.985 & -13.21 & 6.07 & - & - & - & - \\
\hline 160705 & 586.1 & 163.2 & 510.0 & 135.8 & -3.310 & -12.98 & -16.79 & - & - & - & - \\
\hline 160802 & 336.8 & 109.5 & 331.2 & 85.8 & -0.241 & -1.66 & -21.64 & + & - & - & - \\
\hline
\end{tabular}

high rain categories are the most affected by this decrease (38\% each) while the medium categories represent $24 \%$ (Table 6). Spring rainfall (Table 2) highlights the decreasing trend for all stations (100\%). It affects $30 \%, 34 \%$ and $36 \%$ of low, medium and high values respectively (Table 6). Winter and spring rainfall trends are similar to the results of annual rainfall because of the concentrated rainfall in these seasons. For the summer, the situation is completely tilting upwards $(100 \%)$ (Table 3 ). The low and medium values are the most affected (39\% and 34\%) while high categories present $27 \%$ (Table 6). Autumn rainfall (Table 4) confirms the growing trend of the previous season (summer). $94 \%$ of stations display this property. Only one station (160401 located southeast of the basin) showed a decreasing trend. This growth is visible especially in the medium (41\%), high (36\%) and low values $(23 \%)$ (Table 6$)$. The results found perfectly converge with those of Goubanova et al. (2007), in the Mediterranean basin.

Figure 8 presents a comparison of seasonal trends in Tafna precipitation. It highlights that the two seasons (winter and spring) have negative trends, while the others (summer and autumn) show an upward trend. These results are perfectly consistent with the work of Elouissi et al. (2016), on the Macta watershed, underlying catchment area of the Tafna.

A comparison between the arithmetic means of the two halves shows that the majority of stations are in the decreasing zone in winter and spring, while the situation is reversed in summer and autumn (Fig. 9). The latter two make up for the deficit in the first two.

Using the standard deviation comparison, one can note the decreasing values in winter and spring and increasing in summer and autumn (Fig. 10). The increase

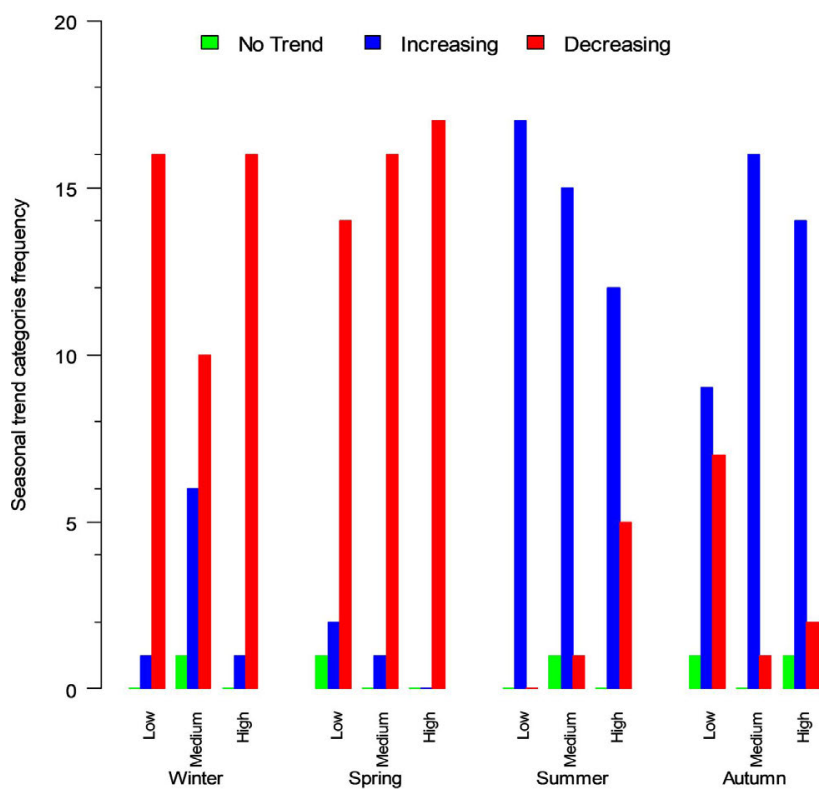

Figure 8 - Seasonal rainfall trends frequencies. 
Table 6 - Trends frequencies by rainfall category.

\begin{tabular}{lcccc}
\hline \multirow{4}{*}{ Winter } & & No trend & Increasing & Decreasing \\
& Low & 0 & 1 & 16 \\
\multirow{4}{*}{ Spring } & Medium & 1 & 6 & 10 \\
& High & 0 & 1 & 16 \\
& Low & 1 & 2 & 14 \\
& Medium & 0 & 1 & 16 \\
\multirow{4}{*}{ Summer } & High & 0 & 0 & 17 \\
& Low & 0 & 17 & 0 \\
& Medium & 1 & 15 & 1 \\
Autumn & High & 0 & 12 & 5 \\
& Low & 1 & 9 & 7 \\
& Medium & 0 & 16 & 1 \\
Annual & High & 1 & 14 & 2 \\
& Low & 2 & 9 & 5 \\
& Medium & 2 & 3 & 11 \\
& High & 0 & 4 & 12 \\
\hline
\end{tabular}
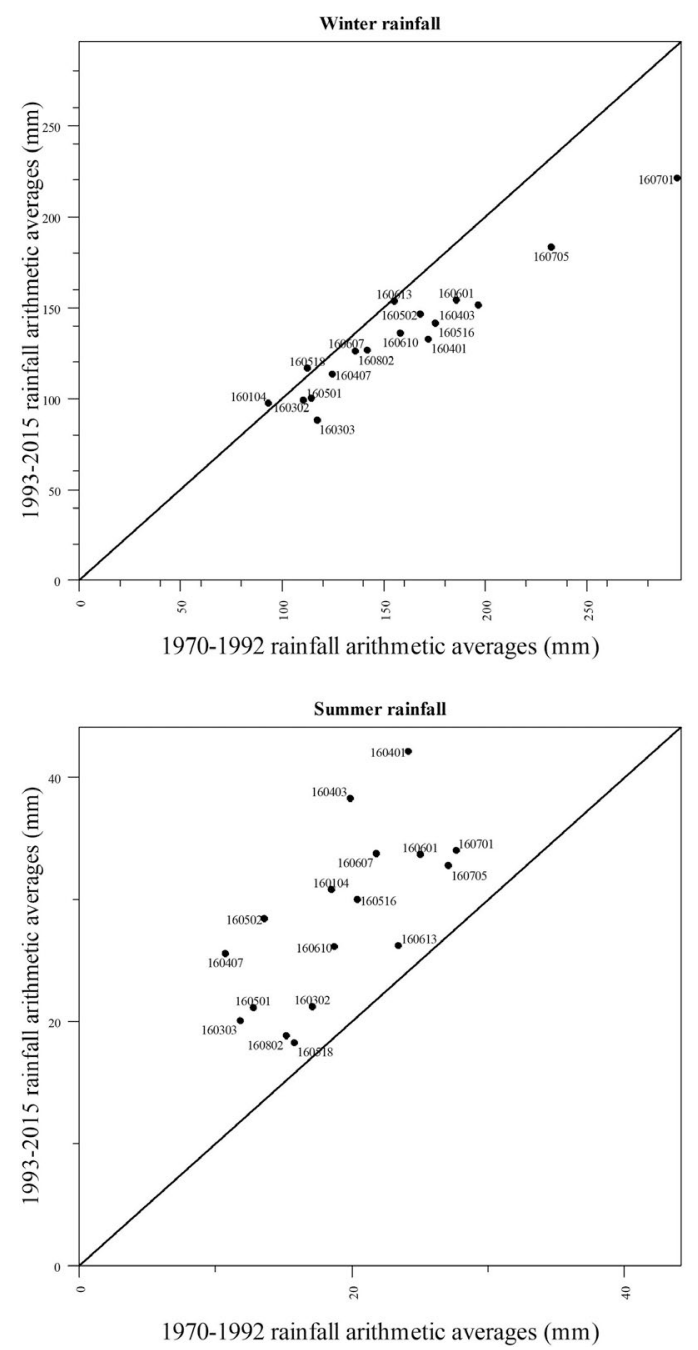

Figure 9 - Seasonal arithmetic average comparison. in standard deviation shows the phenomenon of increase in extreme rain trend mentioned by Benzater et al. (2019). Summer recorded the maximum increase in arithmetic average $(+139.25 \%)$ (at station 160407) and standard deviation (+194.23\%) (at station 160303). It is the season, which currently presents the flooding risk (Li et al., 2020). On the other hand, spring is the season with the greatest decrease in arithmetic average $(-44.99 \%)$ (at station 160303) and standard deviation (-47.48\%) (at station 160501). This indicates that rainfall, in this season, tends, for the most part, to belong to the low category (Wu et al., 2020).

\subsection{Annual trends}

Annual rainfall of most stations (12 stations, 71\%) exhibits downward trends, while 5 stations (29\%) (160104, 160407, 160501, 160518, 160613) have an increasing trend (Table 5). Mainly the medium and high rainfall are affected by the decrease (39\% and $43 \%)$. The
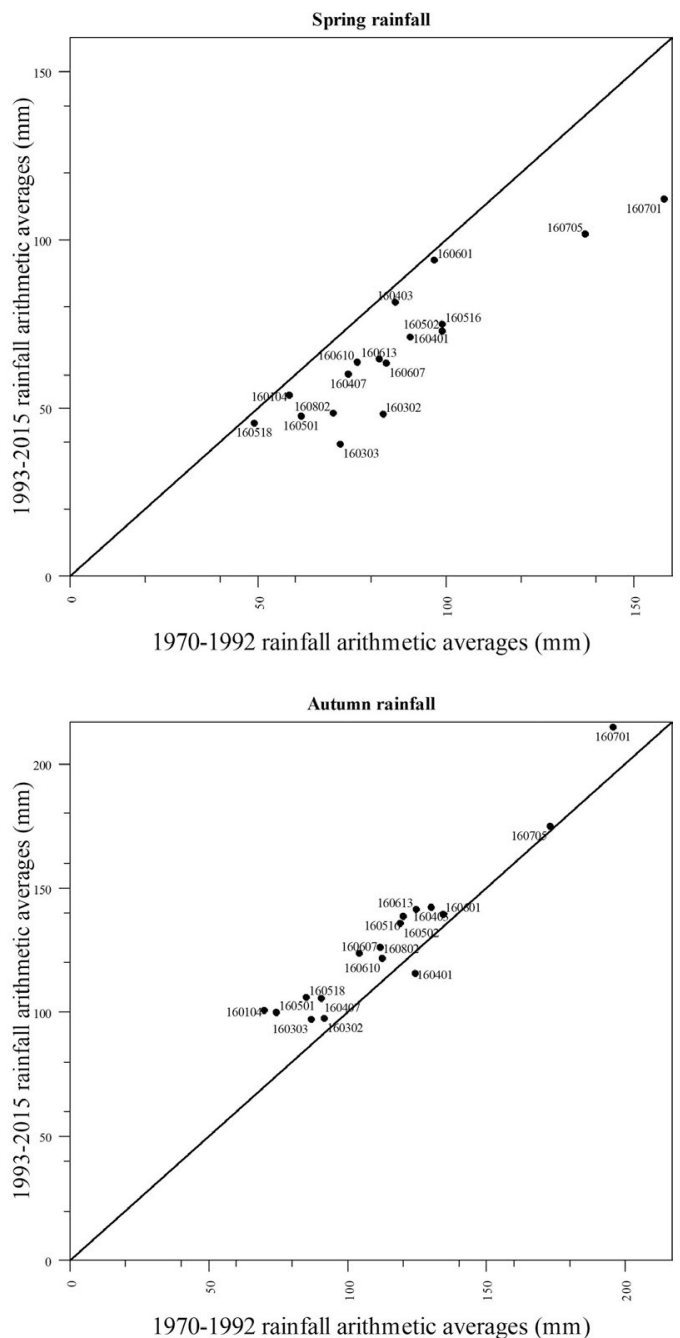

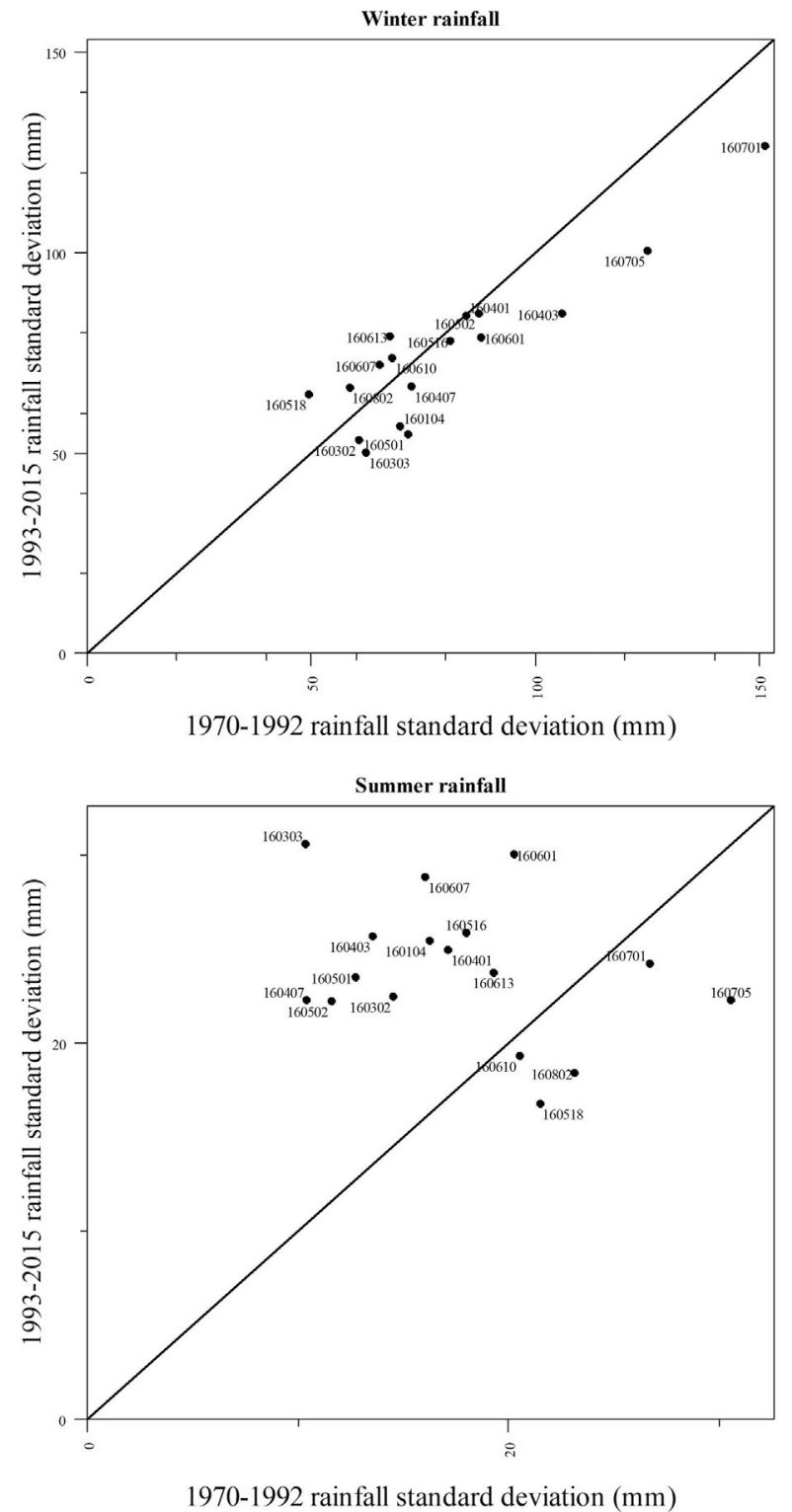

Figure 10 - Seasonal variability comparison.

low categories represent only 18\% (Table 6 and Fig. 11). These results imply that the decreasing annual trends at most stations is due largely to winter and spring rainfall. These results confirm those found by Taibi et al. (2013); Meddi et al. (2013) and Ghenim et al. (2014; 2010).

Using arithmetic averages, 11 stations (160303, 160302 , 160802, 160610, 160401, 160516, 160612, $160403,160601,160705$ and 160701) in the Tafna watershed area have quantitative decreasing as the Fig.12a reveal, because the scatter points fall under the no trend line of 1:1 straight line. Stations 160701 and 160705 (center of the Tafna basin) show the greatest decrease $(-13.21 \%$ and $-12.98 \%$ from Table 5$)$, while at the south of Tafna, station 160104 show the greatest increase $(+19.50 \%)$. From a dispersion view point, the majority of
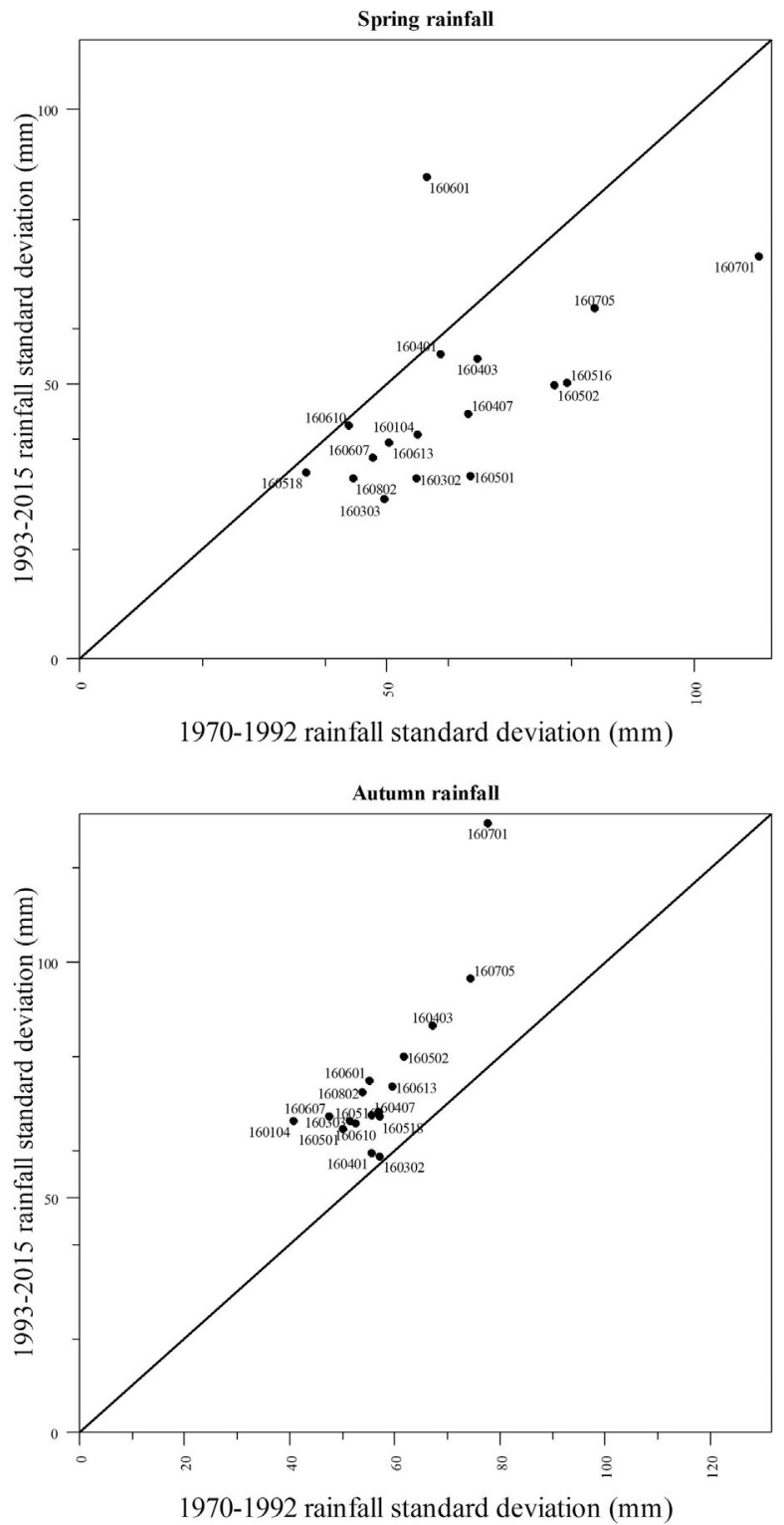

stations have a reduction in their standard deviation (Fig. 12b). This shows that annual rainfalls are close to their average. Station 160501 (160601) presents the maximum decrease $(-35.67 \%)$ (Increase) $(+29.04 \%)$.

\section{Conclusion}

The concept of the ITA method was applied to 17 seasonal and annual rainfall series, located in the Tafna watershed (Northwest Algeria). The observation period is 46 years (1970 to 2015). The seasonal study showed that winter and spring present a decreasing trend of $88 \%$ and $100 \%$ respectively. For winter, the "Low" (38\%) and "High" (38\%) values categories are the most affected by the decrease, while for spring, it is the "Medium" and 


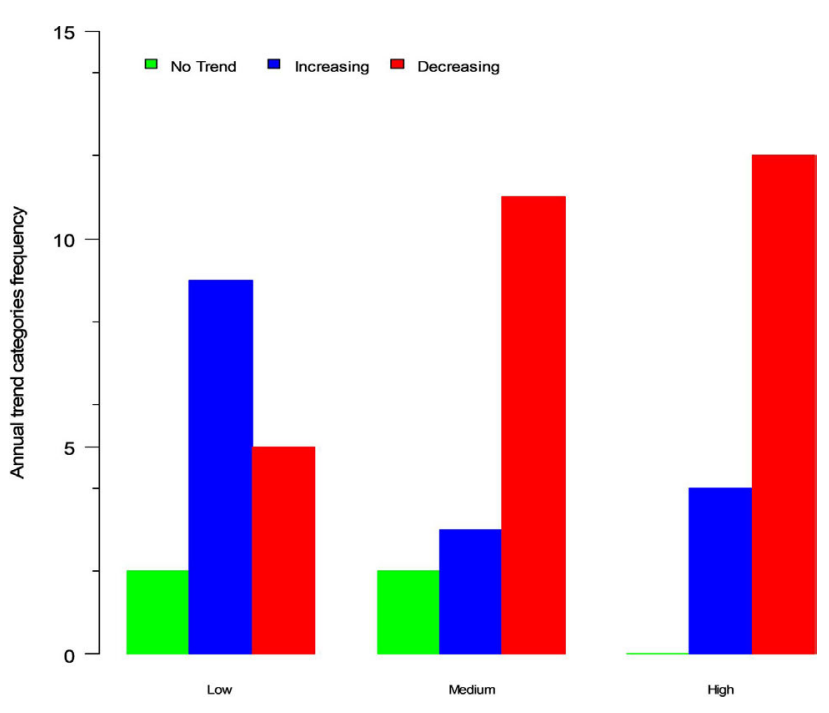

Figure 11 - Annual rainfall trends frequencies.

"High" values, which are affected. In addition, spring is the season with the greatest decrease in arithmetic average $(-44.99 \%)$ and standard deviation $(-47.48 \%)$.

Ghenim et al., 2014 confirmed that there is a deficit in rainfall for the wet season (winter and spring) in the Tafna watershed. This decrease is also linked by, the Mediterranean Oscillation (MO) and the North Atlantic Oscillation (NAO) in the western regions, because they are closer to the Atlantic, particularly with regard to rainfall during wet periods in winter. Several studies have demonstrated that the MO and NAO indices influence the seasonal variability of precipitation in the Mediterranean basin (Lopez et al. 2010; Taibi et al. 2014).

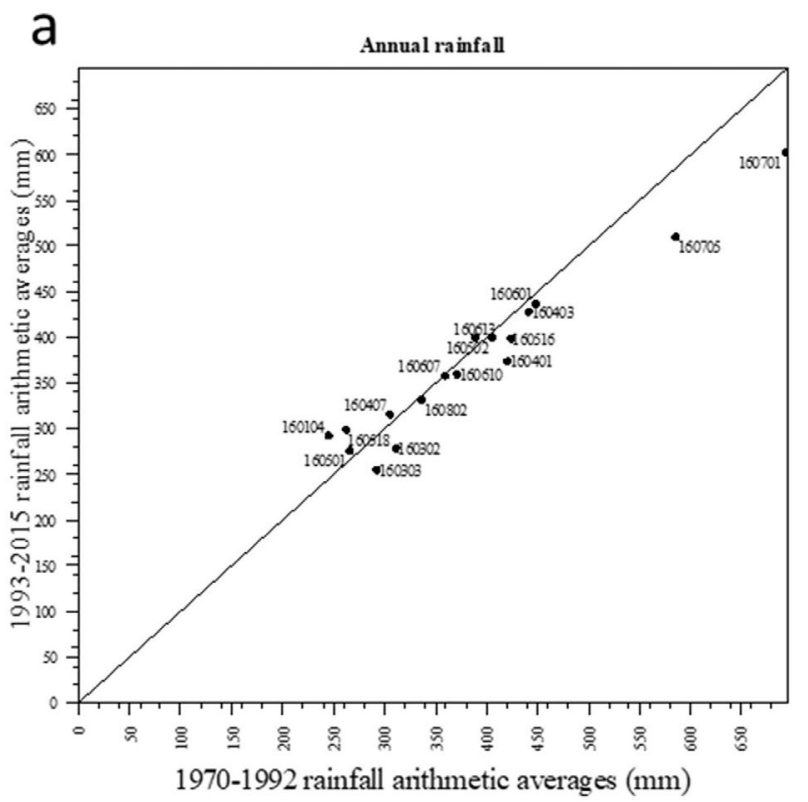

Figure 12 - Annual variability comparison.
The frequency of low precipitation tends to increase in the other two seasons, summer and autumn, the situation completely shifted towards the growing trend $(100 \%$ and $94 \%$ ). In summer, the categories most affected by this increase are the "Low" (39\%) and "High" (36\%) values, while for autumn; these are the "Medium" (41\%) and "High" (36\%) values. Summer recorded the maximum increase in arithmetic average $(+139.25 \%)$ and standard deviation (+194.23\%), and may present a flooding risk in future.

On a yearly scale, a decreasing trend was detected in $71 \%$ of the stations. The categories most affected by this downward are the "Medium" (39\%) and "High" (43\%) values. Most stations are marked by a decrease in their annual arithmetic means. Also, it is noted a dispersion decrease. This can be explained by the geographic location of the Tafna watershed in north-western Algeria, which is influenced by the Mediterranean climate on the one hand, and by the North Atlantic Oscillation (NAO) on the other hand (Hurrell et al., 2003; Xoplaki et al., 2003).

\section{Acknowledgments}

Authors thanks National Agency for Water Resources (ANRH) for providing the observed precipitation data. We extend our gratitude to Pr. Laborde J. for his free Hydrolab software used for data analysis.

\section{References}

Agence de Bassin Hydrographique. Bassin de la Tafna. Document de Synthèse. Oran: Cadastre Hydraulique, 2006.

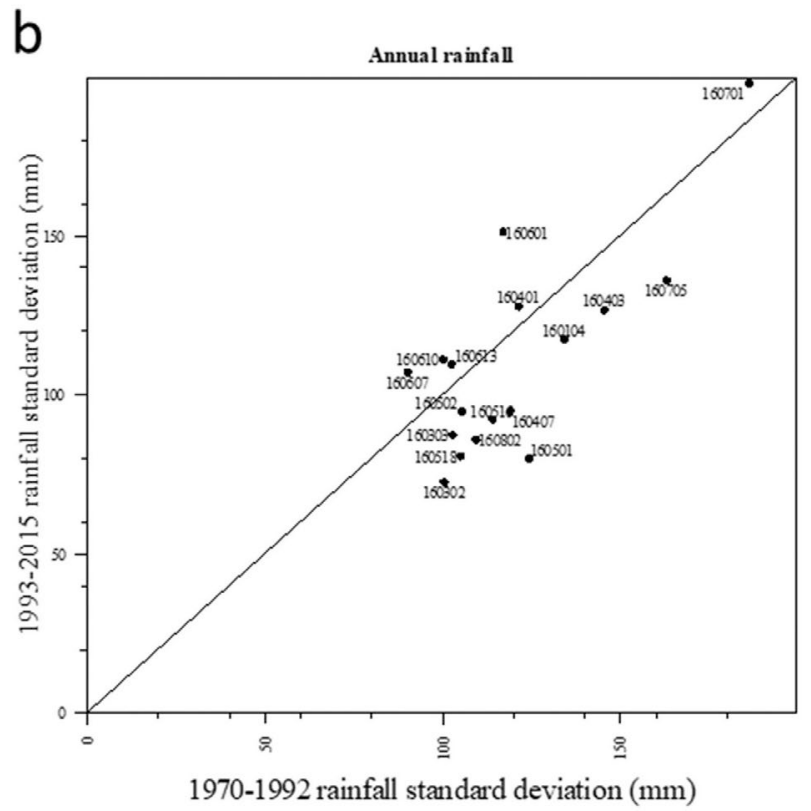


ABOURA, R. Comparaison Phyto-Ecologique Des Atriplexales Situées Au Nord Et Au Sud De Tlemcen. Thèse De Magistère, Université De Abou Bekr Belkaid Tlemcen, 2006.

AHMAD, I.; ZHANG, F.; TAYYAB, M.; ANJUM, M.; ZAMAM, M.; LIU, J.; FARID, U.; SADDIQUE, Q. Spatiotemporal analysis of precipitation variability in annual, seasonal and extreme values over upper Indus River basin. Atmospheric Research, v. 213, n. 2018, p. 346-360, 2018.

BENZATER, B.; ELOUISSI, A.; BENARICHA, B.; HABI, M. Spatio-temporal trends in daily maximum rainfall in northwestern Algeria (Macta watershed case, Algeria). Arabian Journal of Geosciences, v. 12, n. 11, p. 1-18, 2019.

BOUANANI, A. Hydrologie, Transport Solide Et Modelisation Etude De Quelques Sous Bassins De La Tafna (NW - Algérie). Thèse de Doctorat, Abou Bakr Belkaid Université de Tlemcen. 2005.

BOUCHELKIA, H.; BELARBI, F.; REMINI, B. Estimated flows of suspended solids by the statistical analysis of outfall drainage basin of Tafna (Algeria). Soil and Water Research, v. 8, n. 4, p. 63-70, 2013.

CALOIERO, T.; COSCARELLI, R.; FERRARI, E. Application of the innovative trend analysis method for the trend analysis of rainfall anomalies in southern Italy. Water Resources Management, v. 32, n. 15, p. 4971-4983, 2018.

DABANLI, I.; SEN, Z.; YELEGEN, M.; SISMAN, E.; SELEK, B.; GÜÇLÜ, Y. Trend assessment by the innovative-Sen method. Water Resources Management, v. 30, n. 14, p. 111, 2016.

ELOUISSI, A. Changement climatique, impacts et vulnérabilité. Cas du bassin versant de la Macta. Thèse de Doctorat, Abou Bakr Belkaid Université de Tlemcen, 2016.

ELOUISSI, A.; SEN, Z.; HABI, M. Algerian rainfall innovative trend analysis and its implications to Macta watershed. Arabian Journal of Geosciences, v. 9, n. 303, p. 1-12, 2016.

ELOUISSI, A.; HABI, M.; BENARICHA, B.; BOUALEM, S.A. Climate change impact on rainfall spatiotemporal variability (Macta watershed case Algeria). Arabian Journal of Geosciences, v. 10, n. 496, p. 1-14, 2017.

ELMEDDAHI, Y. Les Changements Climatiques Et Leurs Impacts Sur Les Ressources En Eau, Cas Du Bassin Du Cheliff. Thèse de Doctorat, Université Hassiba Benbouali Chlef, 2017.

FATICHI, S.; IVANOV, V.; CAPORALI, E. Assessment of a stochastic downscaling methodology in generating an ensemble of hourly future climate time series. Climate Dynamics, v. 40, n. 8, p. 1841-1861, 2013.

GHENIM, A.N.; MEGNOUNIF, A. Variability and Trend of Annual Maximum Daily Rainfall in Northern Algeria. International Journal of Geophysics, v. 2016, e6820397, 2016.

GHENIM, A.N.; MEGNOUNIF, A.; DJELLOUL, S.M.I.R S.M. Evaluation des changements dans la pluviométrie du bassin versant de la Tafna (nord-ouest de l'Algérie). Eau et Climat au Magheb, v. 2, n. 2014, p. 65-77, 2014.

GHENIM, A.N.; MEGNOUNIF, A. Caractérisation de la sécheresse par les indices spi et SSFI (nord-ouest de l'Algérie). Revue scientifique et Technique, v. 10, n. 18, p. 59-77, 2011.
GHENIM, A.N.; MEGNOUNIF, A.; SEDDINI, A.; TERFOUS, A. Fluctuations hydropluviométriques du bassin versant de l'Oued Tafna à Béni Bahdel (Nord-Ouest Algérien). Sécheresse, v. 21, n. 2, p. 115-120, 2010.

GOUBANOVA, K.; LI, L. Extremes in temperature and precipitation around the Mediterranean basin in an ensemble of future climate scenario simulations. Global and Planetary Change, v. 57, n. 2, p. 27-42, 2007.

HURRELL, J.; KUSHNIR, Y.; OTTERSEN, G.; VISBECK, M. An overview of the north Atlantic oscillation, In the North Atlantic Oscillation: Climatic Signicance and Environmental Impact. American Geophysical Union, v. 134, n. 2003, p. 1-35, 2003.

HYDROLAB. Excel macros developed by JP Laborde helped by $\mathbf{N}$ MOUHOUS. University of Nice Sophia Antipolis and National center of scientific research, 2010. https:// hydrologie.org/MOD/Hydrolab/hydrolab.htm.

IPCC, Intergovernmental Panel on Climate Change. Summary for Policymakers; Fifth Assessment Report of the Intergovernmental Panel on Climate Change. Cambridge University Press: Cambridge, 2013.

IPCC, Intergovernmental Panel on Climate Change. Climate change 2007: The Physical Science Basis Contribution of Working Group I to the Fourth Assessment. Report of the Intergovernmental Panel on Climate Change Cambridge Univ Press New York, 2007.

KISI, O; AY, M. Comparison of Mann-Kendall and innovative trend method for water quality parameters of the Kizilirmak River, Turkey. Journal of Hydrology, v. 513, n. 2014, p. 362-375, 2014.

KISI, O. An innovative method for trend analysis of monthly pan evaporations. Journal of Hydrology, v. 527, n. 2015, p. 1123-1129, 2015.

KREIBICH, H.; DI BALDASSARRE, G.; VOROGUSHYN, S.; AERTS, J.C.J.H.; APEL, H.; ARONICA, G.T.; ARNBJERG-NIELSEN, K.; BOUWER, L.M.; BUBECK, P.; CALOIERO, T. Adaptation to flood risk: Results of international paired flood event studies. Earth's Future, v. 5, n. 10, p. 953-965, 2017.

LABBAN, A.H. Dust Storms over Saudi Arabia: Temporal and Spatial Characteristics, Climatology and Synoptic Case Studies. Thesis in Meteorology, School of Science College of Science Engineering and Health RMIT University, Australia, 2016.

LABORDE, J.P. Eléments d'hydrologie de surface. Antipolis: Course Materials, Professeur Émérite at University of Nice-Sophia 2013.

LI, L.; LI, J.; YU, R. Characteristics of summer regional rainfall events over Ili River Valley in Northwest China. Atmospheric Research, v. 243, n. 2020, p. 1-10, 2020.

LOPEZ, J.; FRANCES, F. Influence of the North Atlantic Oscillation and the western Mediterranean oscillation in the maximum flow events in Spain. International Workshop Advances In Statistical Hydrology, Taormina, Italy, p. 1$11,2010$.

MEDDI, M.; TOUMI, S.; MEHAIGUENE, M. Hydrological Drought in Tafna Basin-Algeria. International Conference on Environmlental Science and Technology (CEST 2013), Athens, 2013. 
MEDDI, M. M.; ARKAMOSE, A.; MEDDI, H. Temporal variability of annual rainfall in the Macta and Tafna Catchments Northwestern Algeria. Water Resources Management, v. 24, n. 14, p. 3817-3833, 2010.

MEDDI, H.; MEDDI, M. Variabilité des précipitations annuelles du Nord-Ouest de l'Algérie. Geographia Technica, v. 20, n. 1, p. 57-65, 2007.

MILLY, P.; BETANCOURT, J.; FALKENMARK, M.; HIRSCH, R.; KUNDZEWICZ, Z.; LETTENMAIER, D.; STOUFFER, R. Stationarity is dead: whither water management? Science, v. 319, n. 5863, p. 573-574, 2008.

MOHORJI, A.M.; SEN, Z.; ALMAZROUI, M. Trend analyses revision and global monthly temperature innovative multiduration analysis. Earth Systems and Environment, v. 1, n. 9, p. 1-13, 2017.

ÖZTOPAL, A.; SEN, Z. Innovative trend methodology applications to precipitation records in Turkey. Water Resources Management, v. 31, n. 3, p. 727-737, 2017.

SAYEMUZZAMAN, M.; MANOJ, K.J.H.A. Seasonal and annual precipitation time series trend analysis in North Carolina United States. Atmospheric Research, v. 137, n. 2014, p. 183-194, 2013.

SEN, Z. Trend identification simulation and application. Journal of Hydrologic Engineering, v. 19, n. 3, p. 635-642, 2014.

SEN, Z. Innovative trend analysis methodology. Journal of Hydrologic Engineering, v. 17, n. 9, p. 1042-1046, 2012.

SUN, F.; RODERICK, M.; FARQUHAR, G. Rainfall statistics, stationarity, and climate change. Proceedings of the National Academy of Sciences of the United States of America, v. 115, n. 10, p. 2305-2310, 2018.

TAIBI, S.; MEDDI, M.; MAHÉ, G.; ASSANIN, A. Variability of Annual and Extreme Rainfall over Northern Algeria and Relationship with Teleconnections Patterns. Proceedings of the Mediterranean Meeting on "Monitoring Modelling and Early Warning of Extreme. Events Triggered by Heavy Rainfalls", PON 01_01503 - MED-FRIEND project. University of Calabria, Cosenza, 2014.

TAIBI, S.; MEDDI, M.; SOUAG, D.; MAHE, G. Evolution et régionalisation des précipitations au nord de l'Algérie
(1936-2009). Proceedings of H01 IAHS-IAPSO-IASPEI, Assembly Gothenburg, Sweden, p. 191-197, 2013.

TALEB, A.; BELAIDI, N.; SANCHEZ-PEREZ, J. M.; VERVIER, P.; SAUVAGE, S.; GAGNEUR, J. The role of the hyporheic zone of a semi-arid gravel bed stream located downstream of a heavily polluted reservoir (Tafna wadi Algeria). River Research and Applications, v. 24, n. 2, p. 183-196, 2008.

WANG, Y.; XU, Y.; TABARI, H.; WANG, J.; WANG, Q.; SONG, S.; HU, Z. Innovative trend analysis of annual and seasonal rainfall in the Yangtze River Delta, eastern China. Atmospheric Research, v. 213, n. 2020, p. 1-14, 2020.

WU, N.; DING, X.; WEN, Z.; CHEN, G.; MENG, Z.; LIN, L.; MIN, J. Contrasting frontal and warm-sector heavy rainfalls over South China during the early-summer rainy season. Atmospheric Research, v. 235, n. 2020, p. 104693 , 2020.

XOPLAKI, E.; GONZÁLEZ-ROUCO, J.; GYALISTRAS, D.; LUTERBACHER, J.; RICKLI, R.; WANNER, H. Interannual summer air temperature variability over Greece and its connection to the large-scale atmospheric circulation and Mediterranean SSTs 1950-1999. Climate Dynamics, v. 20, n. 5, p. 537-554, 2003.

YEVJEVICH, V.; CUNHA, L.; VLACHOS, E. Coping with Droughts. Littleton: Water Resources Publications, 1984.

ZETTAM, A.; TALEB, A.; BELAIDI, N.; SAUVAGE, S.; BOITHIAS, L.; SÁNCHEZ-PÉREZ, J. Modelling hydrology and sediment transport in a semi-arid and anthropized catchment using the swat model: The case of the Tafna River (Northwest Algeria). Water, v. 9, n. 3, p. 216, 2017.

ZHOU, Z.; WANG, L.; LIN, A.; ZHANG, M.; NIU, Z. Innovative trend analysis of solar radiation in China during 19622015. Renewable Energy, v. 119, n. 2018, p. 675-689, 2018.

License information: This is an open-access article distributed under the terms of the Creative Commons Attribution License (type CC-BY), which permits unrestricted use, distribution and reproduction in any medium, provided the original article is properly cited. 